\title{
Physicochemical and Microbiological Assessment of Selected Hand-Dug Wells for Water Quality in Ilesa Metropolis, Southwest Nigeria
}

\author{
Ayodele Jacob OMOTOSO ${ }^{1 *}$, Esther Omotola DADA ${ }^{2}$, \\ Olaoluwa OYEDEJI ${ }^{3}$ \\ ${ }^{1}$ Obafemi Awolowo University, Institute of Ecology and Environmental Studies, Ile-Ife, \\ Nigeria; omotoso.ayodele7@gmail.com (*corresponding author) \\ ${ }^{2} J o s e p h$ Ayo Babalola University, Department of Biological Sciences (Ecology and Environmental Studies), Ikeji-Arakeji, \\ Nigeria; estherdada10@yahoo.com \\ ${ }^{3}$ Obafemi Awolowo University, Department of Microbiology, Ile-Ife, Nigeria; ooyedeji@oauife.edu.ng
}

\begin{abstract}
The present study investigated the physicochemical and microbiological assessment of selected hand-dug wells for water quality in Ilesa metropolis. The aim was to assess the groundwater quality. Twenty-five (25) hand-dug wells were randomly selected and water samples were collected four times spanning through the rainy and dry seasons. Physical parameters (ambient air temperature, water temperature, colour, turbidity and total dissolved solids), chemical ( $\mathrm{pH}$, conductivity, calcium, magnesium, total hardness, chlorides, sulphates, phosphates and nitrates) and microbiological parameters (total heterotrophic bacteria count, Escherichia coli and total heterotrophic fungi count) of the samples were examined. The data obtained were subjected to relevant statistical analysis. Results showed distinct seasonal variation in ambient air temperature, water temperature, $\mathrm{pH}$ and magnesium with highly significant different values at $(\mathrm{p}<0.01)$. Total hardness and sulphates concentrations had high significant different values in the dry season than in the rainy season $(p<0.05)$ while the total heterotrophic bacteria count was significantly different at $(\mathrm{p}<0.001)$. The bacteria species isolated from well water samples were susceptible to pefloxacin and gentamicin. Comparing with international guide levels for drinking water, water samples were poor and unsuitable for drinking. The study concluded that the presence of multiple antibiotic resistant micro-organisms indicates a serious health hazard to the consumers of water obtained from these wells.
\end{abstract}

Keywords: antibiotics; data; hazards; parameters; quality; spanning

\section{Introduction}

Groundwater account for about $98 \%$ of the world's fresh water and it is fairly well distributed throughout the world (Bouwer, 2002). It provides a reasonable constant supply, which is not likely to dry up under natural condition and usually of high quality. The quality of groundwater is of vital importance, whether for industrial or domestics purposes. The composition of surface and groundwater is dependent on natural factors (geological, topographical, meteorological, hydrological and biological) in the drainage basin and varies with seasonal difference in runoff volumes, weather conditions and water levels (Muller, 2001). It supports drinking water supply, for man, livestock, irrigation, industrial and many commercial activities (Vesilind, 1993). Groundwater is generally less susceptible to contamination and pollution when compared to surface water bodies (Zaman, 2002).
In many parts of Nigeria and several other African countries, pipe borne- water supply is either unavailable or irregular especially in the small-sized communities and towns. In most Nigerian cities, the supply of water for domestic purposes has several accompanying inadequacies. According to Sangodoyin (1993), the reasons for these inadequacies include enormous socio-economic rate of development, a growing industrial base, poor planning, insufficient funding, haphazard implementation of programmes, lack of maintenance culture and lack of political will, as well as technically deficient personnel. The national average for access to drinking water was estimated at $32 \%$ of households. Even at that, wide variations existed among the states of the federation, with low values of $6 \%$ and $8 \%$ recorded for Taraba and Benue states respectively and the highest values of $58 \%$ and $78 \%$ recorded in Ogun and Lagos states respectively (Adedeji, 2001). Given such a grim situation, residents are left with no other choice than to seek sources of freshwater from streams, rainfall, and groundwater (by digging wells). 
The assessment of water quality in dug wells is essential because these are often the main sources of water for human consumption in typical African communities (Cho et al., 2010). The well-being of people is dependent on the quality of water which they ingest or otherwise make use of. To live in good health, people need to have access to good quality water in adequate quantity. The parameters for drinking water quality typically fall under three categories namely physical, chemical and microbiological. Physical quality involves such parameters as odour, colour and taste, turbidity and temperature, total dissolved solids. Chemical parameters include $\mathrm{pH}$, total solids, nitrates, sulphates, chlorides, hardness, Biological Oxygen Demand (BOD), Chemical Oxygen Demand (COD) and metals, as well as some other elements (Boleda et al., 2013). Microbiological parameters include coliform bacteria, Streptococci, E. coli and parasites.

The presence of Escherichia coli in drinking water denotes that the water has been faecally contaminated and therefore, presents a potential health risk to households that use them untreated (World Health Organization, 1993). This has grim public health implications as the organisms identified can cause water related diseases like possible outbreaks of typical dysentery or cholera, epidemics and other health problems that have serious complications in children and adults particularly immune-compromised individuals. It has thus become imperative to assess the quality of the water supply from these hand-dug wells and identify the various sources of contaminants in order to ascertain the contamination problems that may confront the consumers.

\section{Materials and Methods}

\section{Geographical location of the study area}

The study area lies within latitude $7^{\circ} 30^{\prime}$ and $7^{\circ} 35^{\prime} \mathrm{N}$ and longitude $4^{\circ} 30^{\prime}$ and $4^{\circ} 34^{\prime} \mathrm{E}$ (Fig. 1). The town covers a total area of about 73.6 square kilometers. The population of Ilesa was at 210,141 in 2006 (NPC, 2006). The climate is humid tropical type with a mean annual temperature of about $28^{\circ} \mathrm{C}$ and a mean annual rainfall of over $1,600 \mathrm{~mm}$. The underlying geology is mainly fine-grained biotitegneiss and schists although quartzite and quartz-schist rocks are common especially on slopes and ridges (Smyth and Montgomery, 1962). The whole area is drained by tributaries of Osun, Sasa and Oora rivers which flow Southward and south-West ward directions. The natural vegetation is the Tropical Rain Forest which could only be found in patches all over the district, but mainly on hills.

\section{Study design and sample collection}

Twenty-five hand-dug wells (designated stations A-Y) as shown in Table 1 , were randomly selected in Ilesa metropolis, and water sampling were conducted four times spanning through the rainy season (June and October 2013) and dry season (March 2013 and January 2014). Two sets of sterilized, sealed and well- labelled sample bottles were used (one set for physico-chemical analysis and the other for microbiological analysis).

Before the water samples were taken, the depth of the wells was estimated by using tape rule to measure their depths. The time for water sampling from each location ranges between $7.30 \mathrm{am}-12.00 \mathrm{pm}$ throughout the periods. The ambient air and well-water temperature of the samples were measured with mercury-in-glass bulb thermometer on the spot of collection. The grid co-ordinates of each station were determined using portable Global Positioning Systems (GPS) equipment (Model GERMIN GPS map 76CSX). Physical observations and description of location and its surrounding were examined, their nearness to the any possible source of pollution. After collection, the water samples were immediately placed in iced box and transported to the Obafemi Awolowo University Ile-Ife for further analysis.

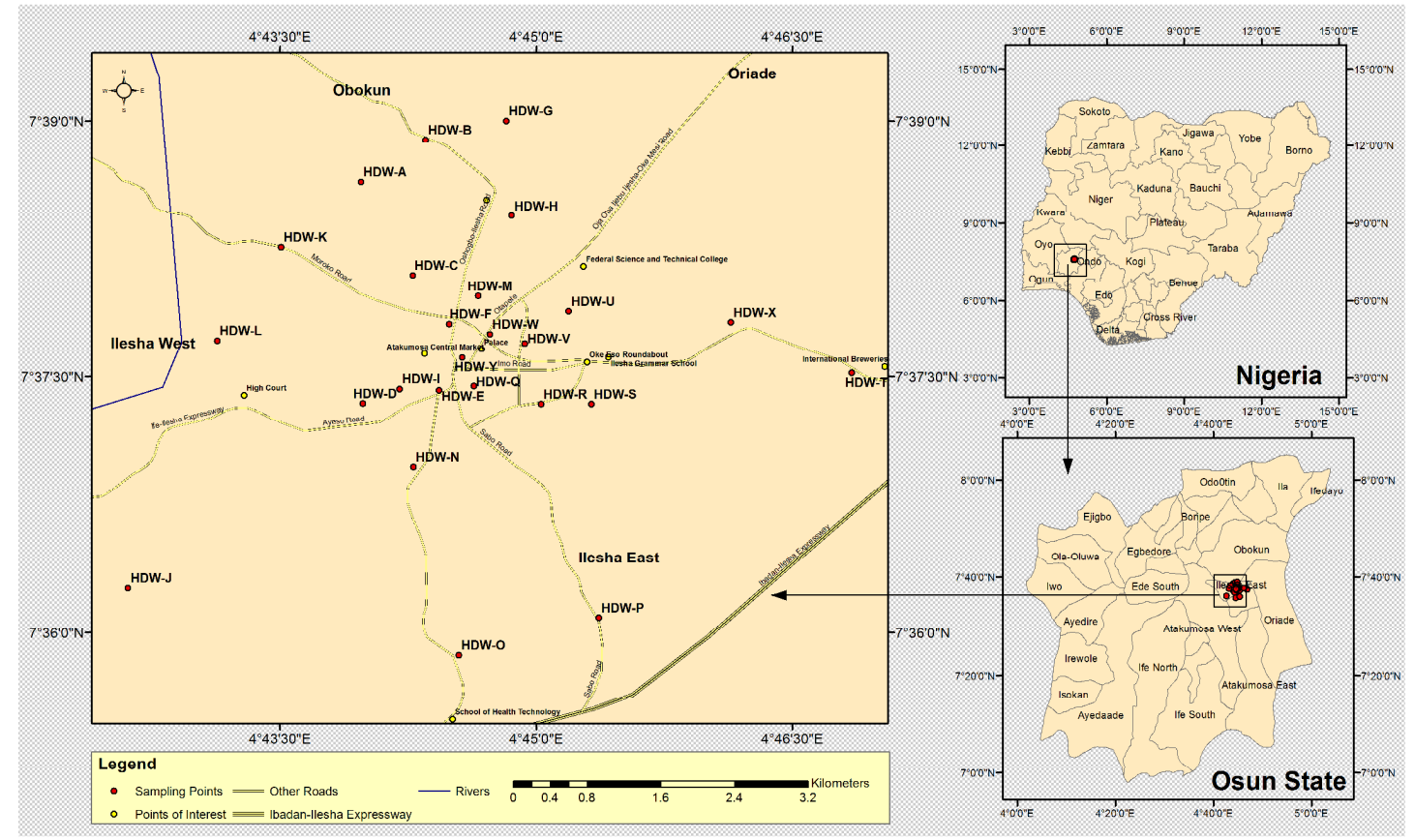

Fig. 1. Map of Ilesa metropolis showing the investigated sampling stations 
54

Table 1. Description of physical features and geographical location of the wells

\begin{tabular}{|c|c|c|c|c|}
\hline Location & Locality & $\begin{array}{l}\text { Global Positioning Systems } \\
\text { (GPS) }\end{array}$ & Depth $(\mathrm{m})$ & Physical Condition of the Hand- Dug Well \\
\hline HDW-A & Ilaje & $\begin{array}{l}07^{\circ} 38^{l} 38.6^{I I} \mathrm{~N} \\
004^{\circ} 43^{l} 58.3^{I I} \mathrm{E}\end{array}$ & 12.60 & Unlined and eroded apron. \\
\hline HDW-B & Oke-Omiru & $\begin{array}{l}07^{\circ} 38^{l} 53.4^{l l} \mathrm{~N} \\
004^{\circ} 44.21^{I l} \mathrm{E}\end{array}$ & 14.14 & Lined and surrounded by overgrown bushes. \\
\hline HDW-C & Ikoti & $\begin{array}{l}07^{\circ} 38^{I} 06.0^{I l} \mathrm{~N} \\
004^{\circ} 44^{I} 16.6^{I l} \mathrm{E}\end{array}$ & 14.30 & Unlined with porous corrugated iron roofing sheet cover. \\
\hline HDW-D & Oke- Iyin & $\begin{array}{l}07^{\circ} 37^{l} 20.8^{I l} \mathrm{~N} \\
004^{\circ} 43^{I} 59.0^{I l} \mathrm{E}\end{array}$ & 11.88 & $\begin{array}{l}\text { Unlined with bad lid and sited much close to toilet and aluminum } \\
\text { melting shop. }\end{array}$ \\
\hline HDW-E & Ita-Balogun & $\begin{array}{l}07^{\circ} 37^{l} 25.3^{I I} \mathrm{~N} \\
004^{\circ} 44^{\prime} 25.8^{I I} \mathrm{E}\end{array}$ & 6.10 & $\begin{array}{l}\text { Unlined with wooden cover, eroded basement and surrounded by } \\
\text { household waste materials. }\end{array}$ \\
\hline HDW-F & Adeti & $\begin{array}{l}007^{\circ} 37^{l} 48.7^{l l} \mathrm{~N} \\
004^{\circ} 44^{l} 29.4^{l l} \mathrm{E}\end{array}$ & 5.40 & Bad lid conditions, very close to toilet. \\
\hline HDW-G & Ibala & $\begin{array}{l}007^{\circ} 39.002^{l} \mathrm{~N} \\
004^{\circ} 44.824^{l} \mathrm{E}\end{array}$ & 3.00 & $\begin{array}{l}\text { Unlined, wooden cover, lower parapet and sited along the water } \\
\text { way. }\end{array}$ \\
\hline HDW-H & Isokun & $\begin{array}{l}07^{\circ} 38.447^{l} \mathrm{~N} \\
004^{\circ} 44.855^{l} \mathrm{E}\end{array}$ & 11.20 & $\begin{array}{l}\text { Unlined, porous cover, eroded basement and sited very close to } \\
\text { burial ground and toilet. }\end{array}$ \\
\hline HDW-I & Odo-Iro & $\begin{array}{l}07^{\circ} 37.430^{l} \mathrm{~N} \\
004^{\circ} 44.199^{l} \mathrm{E}\end{array}$ & 2.40 & Unlined, no parapet and apron and covered with used iron sheets. \\
\hline HDW-J & Ido-Ijesa & $\begin{array}{l}07^{\circ} 36.262^{l} \mathrm{~N} \\
004^{\circ} 42.607^{l} \mathrm{E}\end{array}$ & 12.10 & Sited much close to road side with porous cover. \\
\hline HDW-K & Isale-General & $\begin{array}{l}07^{\circ} 38.262^{l} \mathrm{~N} \\
004^{\circ} 43.504^{l} \mathrm{E}\end{array}$ & 7.50 & $\begin{array}{l}\text { Bad cover, close to gutter with much seepage during the rainy } \\
\text { season. }\end{array}$ \\
\hline HDW-L & Araromi & $\begin{array}{l}07^{\circ} 37.714^{l} \mathrm{~N} \\
004^{0} 43.130^{l} \mathrm{E}\end{array}$ & 10.15 & Unlined and located near household dumpsite. \\
\hline HDW-M & Oke-Ola & $\begin{array}{l}07^{\circ} 37.977^{l} \mathrm{~N} \\
004^{\circ} 44.659^{l} \mathrm{E}\end{array}$ & 3.20 & No protective cover and sited near toilet. \\
\hline HDW-N & Isona & $\begin{array}{l}07^{\circ} 36.976^{l} \mathrm{~N} \\
004^{\circ} 44.279^{l} \mathrm{E}\end{array}$ & 10.90 & Unlined, bad protective cover and surrounded by debris materials. \\
\hline HDW-O & Bolorunduro & $\begin{array}{l}07^{\circ} 35^{I} 52.2^{l l} \mathrm{~N} \\
004^{\circ} 44^{l} 32.7^{I I} \mathrm{E}\end{array}$ & 9.88 & Unlined and sited near the road side. \\
\hline HDW-P & Irojo & $\begin{array}{l}07^{\circ} 36^{l} 05.4^{l l} \mathrm{~N} \\
004^{\circ} 45^{l} 21.9^{I l} \mathrm{E}\end{array}$ & 18.89 & Unlined and located near dumpsite. \\
\hline HDW-Q & Ogburu & $\begin{array}{l}07^{\circ} 37.448^{l} \mathrm{~N} \\
004^{\circ} 44.633^{l} \mathrm{E}\end{array}$ & 1.50 & $\begin{array}{l}\text { Unlined, no parapet and apron, covered with used materials like } \\
\text { iron sheets and tyres. }\end{array}$ \\
\hline HDW-R & Iloro & $\begin{array}{l}07^{\circ} 37.343^{l} \mathrm{~N} \\
004^{\circ} 45.027^{l} \mathrm{E}\end{array}$ & 10.00 & Covered with porous plastic material. \\
\hline HDW-S & Iroye & $\begin{array}{l}07^{\circ} 37.343^{l} \mathrm{~N} \\
004^{\circ} 45.322^{l} \mathrm{E}\end{array}$ & 7.60 & $\begin{array}{l}\text { Located near toilet and covered with used iron and wooden } \\
\text { materials }\end{array}$ \\
\hline HDW-T & Omi- Asoro & $\begin{array}{l}07^{\circ} 37^{l} 31.4^{1 l} \mathrm{~N} \\
004^{\circ} 46^{l} 50.8^{I l} \mathrm{E}\end{array}$ & 19.19 & Unlined and sited much close to the piggery house. \\
\hline HDW-U & Igbaye & $\begin{array}{l}07^{\circ} 37^{I} 53.2^{I l} \mathrm{~N} \\
004^{\circ} 45^{I} 11.3^{I I} \mathrm{E}\end{array}$ & 9.88 & No parapet and very low basement. \\
\hline HDW-V & Ifosan & $\begin{array}{l}07^{\circ} 37.698^{l} \mathrm{~N} \\
004^{\circ} 44.932^{l} \mathrm{E}\end{array}$ & 8.30 & Unlined, poor cover and sited much close to toilet. \\
\hline HDW-W & Ijamo & $\begin{array}{l}07^{\circ} 37.752^{l} \mathrm{~N} \\
004^{\circ} 44.728^{I} \mathrm{E}\end{array}$ & 11.20 & Unlined and sited near road side. \\
\hline HDW-X & Imo & $\begin{array}{l}07^{\circ} 37.822^{l} \mathrm{~N} \\
004^{\circ} 46.139^{l} \mathrm{E}\end{array}$ & 17.00 & Protected well but sited much close to poultry. \\
\hline HDW-Y & Otapete/ Isida & $\begin{array}{l}07^{\circ} 37.613^{l} \mathrm{~N} \\
004^{\circ} 44.565^{l} \mathrm{E}\end{array}$ & 3.00 & Unlined, bad cover and located near slaughter house. \\
\hline
\end{tabular}




\section{Laboratory analyses}

The water samples were analyzed in the laboratory for the following physical parameters: colour, turbidity, air temperature, water temperature, total dissolved solids. The general chemical parameters included: $\mathrm{pH}$, conductivity, calcium, magnesium, total hardness, sulphates, phosphates and chlorides. The water samples were analyzed using standard titrimetric, gravimetric, colorimetric, spectrophotometric methods and standard methods as applicable. The microbiological quality parameters included: total heterotrophic bacteria count (THBC), Escherichia coli (E. coli) count and total heterotrophic fungi count (THFC). The bacterial isolates were characterized using colonial, morphological and biochemical tests. They were further identified using Bergey's manual of Determinative Bacteriology; the microscopic and macroscopic characterization with further identification of fungi isolates were carried out using standard methods. The in vitro antibiotic susceptibility test was carried out using the disc diffusion assay by Bauer $e t$ al. (1966), and the zones of inhibition were measured, compared and interpreted using manual of Clinical Laboratory Standard Institute, (CLSI, 2013).

The data obtained were analyzed using appropriate statistical methods including descriptive statistics, inferential statistics (ANOVA, regression, correlation analyses) and PAST (Paleontological Statistics) statistical software.

\section{Results and Discussion}

Physical parameters of water samples obtained from Hand-dug wells

Ambient air temperature: The highest ambient air temperature of mean \pm value of $27.26 \pm 0.13{ }^{\circ} \mathrm{C}$ was recorded in the dry season while the lowest mean \pm value of $26.80 \pm 0.10^{\circ} \mathrm{C}$ was recorded in the rainy season; there was a significant difference $(p<0.01)$ in seasonal variations during the sampling period (Table 2). This could be due to the thicker cloud cover which had a reducing effect on the solar radiation and in addition, the high temperature observed in dry season was probably associated with high atmospheric temperature, low relative humidity according to Egborge (1978) and Anetekhai (1986).

Water temperature: The highest mean \pm s.e.m water temperature value of $28.04 \pm 0.12{ }^{\circ} \mathrm{C}$ was recorded in the dry season while the lowest mean \pm s.e.m water temperature value of $27.56 \pm 0.11{ }^{\circ} \mathrm{C}$ was recorded in the rainy season; there was significant difference $(p<0.01)$ over the seasonal variations during the sampling period as indicated in Table 2. According to Krenkel and Novotny (1980), increased temperatures cause the growth of undesirable algae and Escherichia coli multiply much more rapidly at elevated temperatures while at lower temperature, the rate of biological activities, that is, the utilization of food supplies for growth and reproduction is slower.

Colour: The mean \pm s.e.m value of colour was higher $(89.43 \pm 13.73 \mathrm{Pt}-\mathrm{Co})$ during the dry season than the rainy season $(87.51 \pm 14.85 \mathrm{Pt}$-Co), however, there was no significant difference in the seasonal variations during the sampling period $(\mathrm{p}>0.05)$ as presented in Table 2. This was not in agreement with the findings of Corbit (2004), who reported that colour was higher during the rainy season than during the dry season indicating that well water significantly increases the concentration of total solids that cause colour in water.

Turbidity: During the seasonal variations, the dry season recorded the highest mean \pm s.e.m value of $7.36 \pm 1.57$ NTU with the rainy season having mean \pm s.e.m value of $4.09 \pm 0.76 \mathrm{NTU}$, but there was no significant difference ( $\mathrm{p}$ $>0.05$ ) (Table 2). Higher turbidity levels are often associated with higher levels of disease-causing microorganisms such as viruses, parasites and some bacteria. These organisms can cause serious health challenges (Reza and Singh, 2009).

Total Dissolved Solids (TDS): The highest mean \pm s.e.m value of total dissolved solids was recorded during the dry season $\left(368 \pm 40.75 \mathrm{mgL}^{-1}\right)$ while the lowest mean \pm s.e.m value was recorded in the rainy season $(328.48 \pm 36.61$ $\left.\mathrm{mgL}^{-1}\right)$, but there was no significant difference during the sampling period $(p>0.05)$ as shown in Table 2. This is consistent with the findings of Bowell et al. (1996) and Efe et al. (2005).

\section{Chemical parameters of water samples obtained from Hand-dug wells}

$p H$ : Highest mean \pm s.e.m $\mathrm{pH}$ value was recorded in the rainy season $(6.45 \pm 0.15)$ while the lowest mean \pm s.e.m value was recorded in the dry season $(5.95 \pm 0.13)$, there was a significant difference $(p<0.01)$ over the two seasons of the annual cycle during the sampling period as presented in Table 2. The high acidity may also lead to concrete structures because of the dissolving and corrosive properties of free carbon dioxide (Krenkel and Novotny, 1980). This season-dependent pattern of low $\mathrm{pH}$ in the dry season was reported by Bello (2002)

Conductivity: The highest conductivity mean \pm s.e.m value $\left(547.71 \pm 61.06 \mu \mathrm{Scm}^{-1}\right)$ was recorded during the rainy season while the lowest mean value was recorded in dry season mean \pm s.e.m value $\left(519.99 \pm 62.36 \mu \mathrm{Scm}^{-1}\right)$. However, there was no significant difference $(\mathrm{p}>0.05)$ during the sampling period as presented in Table 2 . Higher conductivity value in the rainy season than the dry season may be attributed to increase in concentration of salts, ionized substances and the sediments in water (Atef and AlAttar, 2007; Suma et al., 2012).

Calcium: Dry season recorded the highest concentration of calcium ions mean \pm s.e.m of $31.16 \pm 5.22 \mathrm{mgL}^{-1}$ while rainy season recorded the lowest mean \pm s.e.m concentration value of $30.76 \pm 3.66 \mathrm{mgL}^{-1}$. But, there was no significant difference during the sampling period $(p>0.05)$ (Table 3a). The mean value of calcium ions was higher in the dry season than in the rainy season, this may be due to dissolution of $\mathrm{CaCO}_{3}$ and $\mathrm{CaMg}\left(\mathrm{CO}_{3}\right)_{2}$ during recharge (Datta et al., 1996).

Magnesium: The mean \pm s.e.m value of magnesium ions concentration was greatly high in the dry season $(24.07 \pm$ $\left.4.61 \mathrm{mgL}^{-1}\right)$ than in the rainy season $\left(9.53 \pm 1.07 \mathrm{mgL}^{-1}\right)$, the mean value of magnesium ions at various locations were significantly different during the sampling period $(\mathrm{p}<0.01)$ (Table 2). The higher mean value of magnesium ion concentrations during the dry season than rainy season was 
56

significant $(\mathrm{p}<0.01)$ and was in agreement with the work of Anthony et al., (2013). The higher mean value of magnesium ions in the dry season may be attributed to dissolution of magnesium calcite, gypsum and/or dolomite from source rock (Garrels and Mackenzie, 1967).

Total hardness: During sampling period, the highest mean \pm s.e.m value was observed during the dry season $\left(190.44 \pm 29.52 \mathrm{mgL}^{-1}\right)$ than the rainy season of $116.08 \pm$ $12.69 \mathrm{mgL}^{-1}$, there was significant difference over the two seasons considered $(p<0.05)$ as presented in Table 2. Low hardness values during rainy season which may be due to high dilution during rainy season. Total hardness may also be as a result of presence of bicarbonate, sulphate, chlorides and nitrates of calcium and magnesium.

Sulphate: The concentration of sulphate ions increased in the dry season $\left(28.02 \pm 3.10 \mathrm{mgL}^{-1}\right)$ and decreased abruptly in the rainy season $\left(18.91 \pm 2.50 \mathrm{mgL}^{-1}\right)$, there was a significant difference during the sampling period $(\mathrm{p}<$ 0.05 ) as indicated in Table 2. The higher concentration of sulphate ions during the dry season may be attributed to the action of leaching and anthropogenic process in metamorphic environment by release of sulphur gases from industries which is oxidized and enter into the groundwater (Saxena, 2004). High sulphate content in water could cause gastrointestinal irritation (Santra, 2001).

Chloride: The mean chloride ions concentration was highest during the rainy season $\left(65.90 \pm 7.66 \mathrm{mgL}^{-1}\right)$ than during the dry season $\left(62.11 \pm 6.64 \mathrm{mgL}^{-1}\right)$, there was no significant difference during the sampling period $(p>0.05)$ as shown in Table 2. High chloride concentration in groundwater during the rainy season than dry season could be as a result of pollution from sewage, industrial wastes or saline water intrusions according to Bertram and Balance (1998).

Phosphate: During the seasonal variations, highest mean \pm s.e.m value of phosphate ions concentration was recorded in the dry season with mean \pm s.e.m value $(2.83 \pm 0.20 \mathrm{mgL}$ $\left.{ }^{1}\right)$ than the rainy season $\left(2.80 \pm 0.16 \mathrm{mgL}^{-1}\right)$, but there was no significant difference $(\mathrm{p}>0.05)$ (Table 2). This observation agreed with the reports of Egborge (1976), Hall et al. (1977) and Etienne and Bregeon (1992), which confirmed that phosphate concentrations are higher in the dry season. They related the high phosphate concentrations in the dry season to high rate of decomposition of organic matters and mineralization of the mineral salts through evaporation in the dry season.

Nitrate: Dry season recorded highest concentration of nitrate ions of $31.32 \pm 1.85 \mathrm{mgL}^{-1}$ than during the rainy season $\left(30.10 \pm 1.45 \mathrm{mgL}^{-1}\right)$, however, there was no significant in the seasonal variations during the sampling period ( $p>0.05)$ (Table 2). This is in agreement with Adeyemo et al. (2008), who reported that nitrates are usually built up during the dry seasons and that high levels of nitrate ions can only be observed during early rainy seasons. Common sources of these nutrient ions include septic systems, animal manure, decaying organic matter and commercial nitrogen fertilizer (Reza and Singh, 2009). Besides, nitrate is one of the most commonly identified groundwater contaminants and it is primarily regulated in drinking water because excessive levels can cause methaemoglobineamia (blue-baby syndrome).

\section{Microbial parameters of collected samples in Ilesa} metropolis

Total heterotrophic bacterial abundance: Total heterotrophic bacterial count recorded highest population count which was higher in the dry season $\left(1.55 \times 10^{5} \pm 3.10\right.$ $\left.\mathrm{x} 10^{4} \mathrm{cfumL}^{-1}\right)$ than in the rainy season $\left(1.46 \times 10^{4} \pm 3.30 \mathrm{x}\right.$ $\left.10^{3} \mathrm{cfumL}^{-1}\right)$, there was significant difference $(\mathrm{p}<0.01)$ over the seasonal variations during the sampling period (Table 2). This may be attributed to total dissolved solids (TDS) that were found to be higher in the dry season than in the rainy season. This agrees with the observation made by Craun (1988) that the THC present in water isusually directly proportional to the amount of organic matters available as food. The highest total counts in the dry season than the rainy season may be due to the fact that, in the dry season, the volume of these water sources are reduced thereby increasing the concentrations of microorganisms (World Health Organization, 2003).

Abundance of Escherichia coli (E. coli): The population of $E$. coli was higher during the dry season with mean \pm s.e.m value of $3.40 \times 10^{3} \pm 2.51 \times 10^{4}$ cfumL $^{-1}$ than the rainy season with the mean \pm s.e.m value of $1.15 \times 10^{3} \pm 4.17 \mathrm{x}$ $10^{2} \mathrm{cfumL}^{-1}$. However, there was no significant difference $(\mathrm{p}$ $>0.05$ ) over the two seasonal variations during the sampling period (Table 2). This may be due to the fact that, in the dry season the volume of these water sources are reduced thereby increasing the concentrations of microorganisms, this in line with the study of Obi et al. (1998) which explained that, the high number of E. coli in the dry season was due to concentration of the organisms during the dry season. Similarly, Krenkel and Novotny (1980) and Gupta and Gupta (1999) made the same observation as stated above. The higher number may be as a result of animals hurdle around these hand-dug wells in search of drinking water and as such might have deposited their faeces in or near the water sources (World Health Organization, 2003). It is worth noting that the presence of E. coli in the water has a potential health hazards effect.

Population of heterotrophic fungi: Higher mean \pm s.e.m value of total heterotrophic fungi count was recorded in the dry season $\left(2.27 \times 10^{4} \pm 5.6 \times 10^{3} \mathrm{cfumL}^{-1}\right)$ while the lower mean \pm s.e.m value $2.26 \times 10^{4} \pm 4.58 \times 10^{3} \mathrm{cfumL}^{-1}$ was recorded in the rainy season, but there was no significant difference $(p>0.05)$ over the seasonal variations as shown in Table 2. This may be attributed to total dissolved solids (TDS), colour, temperature, turbidity of water and other mineral salts that were found to be higher in the dry season than in the rainy season which favour increased fungi population because reduction in water volume would increase the concentrations of microorganisms as stated by Obi et al. (1998). Results from studies on taste and odour problems in drinking water indicated the occurrence of fungi as an important causative agent for these sensoric changes (Nystro" $\mathrm{m}$ et al., 1992; Montiel et al., 1999), and bad tastes in water have been attributed to microfungi for decades (Kelley et al., 2003).

\section{Antibiotic susceptibility testing of bacteria isolates}

The susceptibility of bacteria isolates to various classes of antibiotics was employed. The bacteria species isolated from hand-dug well water samples from Ilesa metropolis were 
very susceptible to pefloxacin and gentamicin while they were very resistant to ciprofloxacin amoxicillin, streptomycin, augmentin and sparfloxacin as showed in Table $3 \mathrm{a}$ and $3 \mathrm{~b}$. The resistance of the bacterial isolates to commonly used antibiotics as obtained in this study indicates the potential dangers they may pose to the health of the public. It has been reported that major epidemics in the World had been linked with resistant pathogens (Levy, 2001; Canton et al., 2003). The high levels of resistance obtained may be due to the prevalence of fake and substandard drugs available in many developing countries like Nigeria (Kothari and Sagar, 2008). Also attached to this phenomenon is the inappropriate use of antimicrobial agents without proper prescriptions from qualified medical personnel. Since the antibiotics persist in the environment (Zuccato et al., 2000), bacteria are then exposed to sub-optimal doses of the drugs, thereby making them resistant. Some of the selected hand dug wells were very close to the major roads where they receive toxic gases from automobile exhausts (cars, lorries and trucks) and this could also cause resistance because of the toxic effect of hydrocarbons.

Table 2. Seasonal variations of selected hand-dug well water samples from Ilesa Metropolis

\begin{tabular}{|c|c|c|c|c|}
\hline \multirow{2}{*}{ Parameter } & \multirow{2}{*}{$\begin{array}{c}\text { Dry season } \\
(\text { mean } \pm \text { s.e.m) }\end{array}$} & \multirow{2}{*}{$\begin{array}{c}\text { Rainy season } \\
(\text { mean } \pm \text { s.e.m) }\end{array}$} & \multicolumn{2}{|c|}{ ANOVA } \\
\hline & & & $\mathrm{F}$ & $\mathrm{P}$ \\
\hline Ambient air temperature $\left({ }^{\circ} \mathrm{C}\right)$ & $27.26 \pm 0.13$ & $26.8 \pm 0.10$ & 7.875 & $0.00604^{* *}$ \\
\hline Water temperature $\left({ }^{\circ} \mathrm{C}\right)$ & $28.04 \pm 0.12$ & $27.56 \pm 0.11$ & 8.720 & $0.00394^{* *}$ \\
\hline Colour (Pt-Co) & $89.43 \pm 13.72$ & $87.51 \pm 14.85$ & 0.00898 & 0.925 \\
\hline Turbidity (NTU) & $7.36 \pm 1.57$ & $4.09 \pm 0.76$ & 3.498 & 0.0644 \\
\hline $\mathrm{pH}$ & $5.95 \pm 0.13$ & $6.45 \pm 0.15$ & 6.48 & $0.0125^{* *}$ \\
\hline Conductivity $\left(\mu \mathrm{Scm}^{-1}\right)$ & $519.99 \pm 62.36$ & $547.71 \pm 61.06$ & 0.1008 & 0.7516 \\
\hline Total Dissolved Solids $\left(\mathrm{mgL}^{-1}\right)$ & $368.14 \pm 40.75$ & $328.48 \pm 36.61$ & 0.5239 & 0.4709 \\
\hline Calcium $\left(\mathrm{mgL}^{-1}\right)$ & $31.16 \pm 5.22$ & $30.76 \pm 3.66$ & 0.003895 & 0.9504 \\
\hline Magnesium $\left(\mathrm{mgL}^{-1}\right)$ & $24.07 \pm 4.61$ & $9.53 \pm 1.07$ & 9.435 & $0.002755^{* *}$ \\
\hline Total Hardness (mgL $\left.{ }^{-1}\right)$ & $190.44 \pm 29.52$ & $116.08 \pm 12.69$ & 5.355 & $0.02275^{*}$ \\
\hline Sulphate $\left(\mathrm{mgL}^{-1}\right)$ & $28.02 \pm 3.10$ & $18.91 \pm 2.50$ & 5.238 & $0.02425^{*}$ \\
\hline Chloride $\left(\mathrm{mgL}^{-1}\right)$ & $62.11 \pm 6.64$ & $65.90 \pm 7.66$ & 0.14 & 0.7091 \\
\hline Phosphate $\left(\mathrm{mgL}^{-1}\right)$ & $2.83 \pm 0.20$ & $2.80 \pm 0.16$ & 0.02012 & 0.8875 \\
\hline Nitrate $\left(\mathrm{mgL}^{-1}\right)$ & $31.32 \pm 1.85$ & $30.10 \pm 1.45$ & 0.268 & 0.6059 \\
\hline $\begin{array}{l}\text { Total Heterotrophic Bacteria } \\
\text { Count }\left(\mathrm{cfumL}^{-1}\right)\end{array}$ & $154874.3 \pm 31005.96$ & $14640.10 \pm 3297.85$ & 20.23 & $1.891 \mathrm{E}-05^{* * *}$ \\
\hline Escherichia coli $\left(\mathrm{cfumL}^{-1}\right)$ & $3396.42 \pm 2511.63$ & $1150.87 \pm 417.66$ & 0.9667 & 0.3349 \\
\hline $\begin{array}{l}\text { Total Heterotrophic Fungi Count } \\
\qquad\left(\mathrm{cfumL}^{-1}\right)\end{array}$ & $22657.69 \pm 5610.60$ & $22645.96 \pm 4576.87$ & $2.643 \mathrm{E}-06$ & 0.9987 \\
\hline
\end{tabular}

Table 3a. Percentage frequency of antibiotic susceptibility pattern for gram positive bacterial isolates

\begin{tabular}{|c|c|c|c|c|}
\hline \multirow[b]{2}{*}{$\mathrm{S} / \mathrm{N}$} & \multirow[b]{2}{*}{ Antibiotics } & \multicolumn{3}{|c|}{ Percentage (\%) Frequency } \\
\hline & & Resistance & Intermediate & Susceptible \\
\hline 1 & Zinnacef $(\mathrm{Z})$ & 85 & 7.7 & 7.7 \\
\hline 2 & Amoxacillin (AM) & 62 & 15.4 & 23.1 \\
\hline 3 & Rocephin (R) & 31 & 38.5 & 31 \\
\hline 4 & Ciprofloxacin (CPX) & 77 & 23.1 & 0 \\
\hline 5 & Streptomycin (STR) & 39 & 0 & 62 \\
\hline 6 & Septrin (SXT) & 7.7 & 31 & 62 \\
\hline 7 & Erythromycin (ERY) & 54 & 46 & 0 \\
\hline 8 & Pefloxacin (PEF) & 0 & 7.7 & 92 \\
\hline 9 & Gentamicin $(\mathrm{CN})$ & 0 & 7.7 & 92 \\
\hline 10 & Ampiclox (APX) & 54 & 23.1 & 23.1 \\
\hline
\end{tabular}

Table 3b. Percentage frequency of antibiotic susceptibility pattern for gram negative bacterial isolates

\begin{tabular}{|c|c|c|c|c|}
\hline \multirow[b]{2}{*}{$\mathrm{S} / \mathrm{N}$} & \multirow[b]{2}{*}{ Antibiotics } & \multicolumn{3}{|c|}{ Percentage (\%) Frequency } \\
\hline & & Resistance & Intermediate & Susceptible \\
\hline 1 & Septrin (SXT) & 85 & 0 & 15.4 \\
\hline 2 & Chloranphenicol $(\mathrm{CH})$ & 77 & 15.4 & 7.7 \\
\hline 3 & Sparfloxacin (SP) & 92 & 0 & 7.7 \\
\hline 4 & Amoxacillin (AM) & 92 & 0 & 7.7 \\
\hline 5 & Augmentin (AU) & 100 & 0 & 0 \\
\hline 6 & Ciprofloxacin (CPX) & 77 & 23.1 & 0 \\
\hline 7 & Gentamicin $(\mathrm{CN})$ & 7.7 & 15.4 & 77 \\
\hline 8 & Pefloxacin (PEF) & 7.7 & 0 & 92 \\
\hline 9 & Streptomycin (S) & 92 & 0 & 7.7 \\
\hline 10 & Tarivid (OFX) & 84.6 & 7.7 & 7.7 \\
\hline
\end{tabular}


58

\section{Conclusions}

The study concluded that colour, turbidity, $\mathrm{pH}$, phosphates, total hardness, total heterotrophic bacteria, Escherichia coli and total heterotrophic fungi values of the water were above the maximum permitted levels of Nigerian Standard for drinking water quality, European Union for water quality and World Health Organization safety guidelines for drinking water. There were presences of multiple antibiotic resistant bacteria. Thus, microbiologically, the water samples were found to be unfit for human consumption without prior treatment.

\section{Recommendations}

The failure to provide safe potable water to the rapidly growing rural and urban population nationwide is driving people into desperation. Hence, individuals are forced by these circumstances to extract groundwater at very unsafe location and depth. Based on the research findings and conclusions, it is recommended that people in the study area should:

a. Boil and filter their groundwater before drinking.

b. The existing wells should be well kept and should be well developed while the uncovered ones are to be provided with good covers.

c. The wells should always be properly lined or ringed to avoid seepage during the dry season.

d. Put pressure on government to re-introduce house to house sanitary inspections to check the proximity of latrines to wells.

e. Access to wells by domestic and grazing animals should be restricted with an enclosure by fencing.

f. Finally, the Federal Government should put up a national action plan to check the possible spread of waterborne diseases and sponsor research in the rural areas on water borne diseases as a means of disaster risk reduction.

\section{References}

Adedeji AO (2001). Quality of drinking water in Lagos State. Discovery Innovation 7:56.

Adeyemo OK, Adedokun OA, Yusuf RK, Adeleye EA (2008). Seasonal changes in physico-chemical parameter and nutrient load of river sediments in Ibadan City, Nigeria. Global Nest. The International Journal 10(3):326-336.

Anetekhai MA (1986). Aspects of the bioecology of the African river prawn Macrobrachium vollenhovenii (Herklots) in Asejire Lake, Oyo State, Nigeria. $\mathrm{PhD}$ Thesis, University of Ibadan.

Anthony KRN, Diaz-Pulido G, Verlinden N, Tilbrook B, Andersson AJ (2013). Benthic buffers and boosters of ocean acidification on coral reefs. Biogeosciences 10(7):4897-4909.

Atef M, Al-Attar (2007). The influence of nickel exposure on selected physiological parameters and gill structure in the teleost fish, Oreochromis niloticus. Journal of Biological Science 7(1):77-85.

Bauer AW, Kirby MM, Sheris JS, Turek M (1969). Antibiotic susceptibility testing by a standardized single disk method. American Journal Clinical Pathology 45(4):939-396.
Bello MH (2002). Geoelectric and geochemical evaluation of groundwater quality at Olusosun refuse dumpsite, Ojota Lagos. Unpublished Report.

Bertram J, Balance R (1998). Water quality monitoring: a practical guide to the design and implementation of freshwater quality studies and monitoring programmes. CRC Press.

Black RE (1993). Persistent diarrhea in children in developing countries. Pediatric Infection Diseases Journal 12:751-761.

Boleda MR, Galceran MT, Ventura F (2011). Behavior of pharmaceuticals and drugs of abuse in a drinking water treatment plant (DWTP) using combined conventional and ultrafiltration and reverse osmosis (UF/RO) treatments. Environmental Pollution 159(6):1584-1591.

Bouwer H (2002). Artificial recharge of groundwater. Hydrology Engineering Hydro-geology Journal 10(1):121-142.

Bowell RJ, McEdonneyS, Warren A, Bwankuzo M (1996). Biogeochemical factors affecting groundwater quality in Tanzania. Environmental Geochemistry and Health, British Geological Survey 113:107-130.

Canton R, Coque TM, Baquero F (2003). Multi-resistant gram-negative bacilli: from epidemics to endemics. Current Opinion in Infectious Diseases 16:315-325.

Cho DI, Ogwang T, Opio C (2010). Simplifying the water poverty index. Social Indicator Research 97(2):257-267.

Clinical and Laboratory Standards Institute (CLSI) (2013). Performance standards for antimicrobial disk susceptibility tests. Approved standard M2-A10. Wayne, P.A: Clinical and Laboratory Standards Institute.

Corbit RA (2004). Standard handbook of environmental engineering. McGraw-Hill Companies. New York, USA, 2nded pp 6-19.

Craun FG (1988). Surface water supplies and health. Journal America Water Works Association 80:40-52.

Datta PS, Bhattacharya SK, Tyagi SK (1996). 180 Studies on recharge of phreatic aquifers and groundwater flow-paths of mixing in the Delhi area. Journal of Hydrology 176(1-4):25-36.

Efe SI, Ogba FE, Horsfall M Jnr, Akporhinor EE (2005). Seasonal variations of physicochemical characteristics in water resources quality in western Niger Delta region, Nigeria Journal Applied Science Environmental Management 9(1):191-195.

Egborge ABM (1976). The effect of impoundment on the water chemistry of Lake Asejire. Nigerian Freshwater Biology 9:403-412.

Egborge ABM (1978). Observations on the diurnal changes in some physicochemical variables of Lake Asejire, a new impoundment in Nigeria. Poleonological Archaeology Hydrobiology 26(2):61-73.

Etienne M, Bregeon N (1992). A quick enzymatic quantitative analysis of histamine in tuna by microplate reader. Proceeding of the 22 nd annual meeting of the western European fish technologists association.

Garrels RM, Mackenzie FT (1967). Origin of the chemical composition of some springs and lakes. Chemical Series 67:222-242.

Gupta BK, Gupta RR (1999). Physicochemical and biological study of drinking water in Satna Madhya Pradesh. Pollution Research 18(4):523-525.

Hall A, Valente MI, Davis B (1977). The Zambesi River in Mozambique: the physico-chemical status of the middle and lower Zambezi prior to the closure of the Cabora Bassa Dam. Freshwater Biology 7(3):187-206.

KelleyJ Kinsey, G Paterson, Brayford D (2003). Identification and control of fungi in distribution systems. AWWA Research Foundation and 
American Water Works Association, Denver, Colombia.

Kothari A, Sagar V (2008). Antibiotic resistance in pathogens causing community acquired urinary tract infections in India: a multi-centre study. Journal of Infectious Diseases 2:354-358.

Krenkel AP, Novotny V (1980). Water quality management. Academic Press, NC. (London) Ltd pp 46-69.

Levy SB (2001). Antibiotic resistance: consequences of inaction. Clinical Infectious Diseases 33: S124S129.

Montiel A, Rigal S, Welte B (1999). Study of the origin of musty taste in the drinkingwater supply. Water Science and Technology 40:171-177.

Muller BA (2001). Residential water source and the risk of childhood brain tumors. Environmental Health Perspective 109(6):551-556.

Nystrom A, Grimvall A, Krantz-Rulcker C, Savenhed R, Akerstrand K (1992). Drinking water off-flavour caused by 2, 4, 6-trichloroanisole. Water Science and Technology 25:241-249.

Obi CL, Coker AO, Epoke J, Ndip RN (1998). Distributional patterns of bacterial diarrhoeagenic agents and antibiograms of isolates from diarrhoeaic and non-diarrhoeaic patients in urban and rural areas of Nigeria. The Central African Journal of Medicine 44(9):223-229.

Reza R, Singh G (2009). Physico-chemical analysis of ground water in Angul-talcher region of Orissa, India. Journal of American Science 5(5):53-58.

Sangodoyin AY (1993). Consideration on contamination of groundwater by waste disposal systems in Nigeria. Environmental Technology 14:957-964.
Santra SC (2001). Water pollution (Drinking water standards by World Health Organization, 1971). In: Environmental Science, New Central BookAgency (P)Ltd., Calcutta.

Saxena VK (2004). Geothermal resources of India. Allied Publishers Pvt Ltd,, New Delhi, India.

Smyth AJ, Montgomery RF (1962). Soils and land use in Central Western Nigeria.

Vesilind PJ (1993). The Middle East's WATER critical resource. National Geographic 183(5):38-70.

World Health Organization (1993). Improving water and sanitation hygiene behaviours for the reduction of diarrhoeal disease: The report of an informal consultation. World Health Organization, Geneva. WHO/CDD/CWSWHO.

World Health Organization (1997). Guidelines for drinking-water quality, 2nd ed. Vol.2. Health criteria and other supporting information. World Health Organization, Geneva.

World Health Organization (2003). Assessing microbial safety of drinking water improving approaches and methods: Improving approaches and methods. OECD Publishing.

Zaman CL (2002). A nested case-control study of methemoglobinemia risk factors in children of Transylvania, Romania. Environmental Health Perspectives 110(8):817-822.

Zuccato E, Calamar D, Natangelo M, Fanelli R (2000). Presence of therapeutic drugs in the environment. The Lancet 355(9217):17891790. 